American Journal of Applied Sciences 5 (10): 1318-1321, 2008

ISSN 1546-9239

(C) 2008 Science Publications

\title{
Simulation Studies on A Cross Flow Plate Fin Heat Exchanger
}

\author{
M. Thirumarimurugan, T. Kannadasan and E. Ramasamy \\ Department of Chemical Engineering, Coimbatore Institute of Technology, \\ Coimbatore 641 014, India
}

\begin{abstract}
Compact heat exchangers which were initially developed for the aerospace industries in the 1940s have been considerably improved in the past few years. The main reasons for the good performance of compact heat exchangers are their special design which includes turbulent which in turn use high heat transfer coefficient and resists fouling, and maximum temperature driving force between the hot and cold fluids. Numerous types use special enhancement techniques to achieve the required heat transfer in smaller plot areas and, in many cases, less initial investment. One such type of compact heat exchanger is the Plate-fin heat exchanger. The complexity of compact heat exchanger design equations results from the exchangers unique ability to transfer heat between multiple process streams and a wide array of possible flow configurations. This paper presents the performance evaluation of cross flow plate fin heat exchanger with several different Gas-Liquid systems. Experimental results such as exchanger effectiveness, overall heat transfer coefficients were calculated for the flow systems of Cross flow Heat Exchangers. A steady state model for the outlet temperature of both the cold and hot fluid and overall heat transfer coefficient of a plate-fin cross flow heat exchanger was developed and simulated using MATLAB, which was verified with the experiments conducted.
\end{abstract}

Key words: Overall heat transfer coefficient, surface effectiveness, exchanger effectiveness, fin effectiveness

\section{INTRODUCTION}

Heat Exchanger is process equipment designed for effective transfer of heat energy between two fluids (a hot fluid and a cold fluid). Many types of heat exchangers are used in industry, such as shell and tube, double pipe, compact heat exchangers etc, which vary both in application and design. The choice of heat exchanger type directly affects the process performance and also influences plant size, plant layout, length of pipe runs, and the strength and size of supporting structures. Plate fin heat exchangers form one of the main categories of compact heat exchangers designed to pack a high heat transfer capacity into small volume. Heat transfer is mainly function of surface area; therefore by increasing surface area per unit volume high performance can be obtained with a small size heat exchanger. Performance analysis of cross flow heat exchanger was carried out. ${ }^{[3]}$ by using air as one of the fluid. An approach to fouling allowances in the design of compact heat exchangers was discussed. ${ }^{[4]}$ An approximate method for transient behavior of finned tubes cross flow heat exchangers was discussed. ${ }^{[6]}$. In the present study, experimental investigations were carried by using miscible systems. Steam is the hot fluid, whereas Water and Acetic acid-Water miscible solution serves as cold fluid. A series of runs were made between steam and water, steam and Acetic acid solution. In addition to, the volume fraction of Acetic acid was varied and the experiment was held. The flow rate of the cold fluid is maintained from $30 \mathrm{lph}$ to 300 lph for Cross flow Heat Exchanger, and the volume fraction of Acetic acid is varied from $10-50 \%$. Experimental results such as exchanger effectiveness, overall heat transfer coefficients were calculated for the flow systems of Cross flow Plate fin Heat Exchanger. A steady state model for the outlet temperature of both the cold and hot fluid and overall heat transfer coefficient of a plate-fin cross flow heat exchanger was developed and simulated using MATLAB, which was verified with the experiments conducted.

\section{MATERIALS AND METHODS}

\section{Experimental studies}

Experimental setup: The Plate fin heat exchanger, in which heat transfer studies are to be carried out, was fabricated with Aluminum as the material of

Corresponding Author: $\quad$ M. Thirumarimurugan, Department of Chemical Engineering, Coimbatore Institute of Technology, Coimbatore 641 014. India 
Am. J. Applied Sci., 5 (10): 1318-1321, 2008

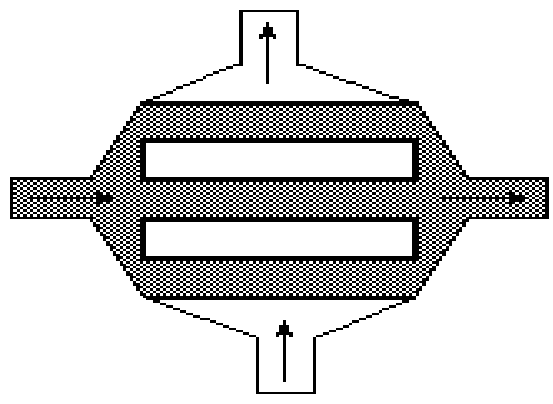

Fig. 1: A cross-flow heat exchanger

construction. The basic element consists of two plates, a strip of corrugated sheet and edge- sealing bars. Here, instead of the edge sealing bars, the flat plate was folded on both sides thus providing an enclosure to the corrugations. The flat plates are termed as Primary surface and the corrugations as 'secondary surface'. The corrugations were welded to the flat plates. Figure 1 shows the schematic of cross flow plate-fin exchanger.

Experimental procedure: The inlet temperature $\left(t_{i}\right)$ of the cold fluid is measured. The pump is operated and the required water or Acetic acid water mixture flow rate is fixed using the valve. The Steam generator is switched on and the steam inlet temperature $\left(\mathrm{T}_{\mathrm{i}}\right)$ is set to a constant value. The steam flow rate is controlled by the ball valve. As the fluid flow starts on the both sides the phenomenon of heat transfer takes place between hot and cold fluids through the walls of the Tubes. The flow system is allowed to attain steady state. The outlet temperatures of condensate $\left(\mathrm{T}_{\mathrm{o}}\right)$ and the cold fluid $\left(\mathrm{t}_{\mathrm{o}}\right)$ are measured. The condensate flow rate is measured at the exit of the Shell. Then the flow rate of the cold fluid is varied and the above procedures are repeated

Experimental observations: Experiments were carried out on five systems having different compositions of Acetic acid and water according to the procedure. The observations are tabulated in the Table 1, 2.

Fin effectiveness, Surface effectiveness, Exchanger effectiveness, the film coefficients for both hot and cold fluids, Overall heat transfer coefficient and NTU calculations for the above observed readings are given in the Table 3, 4 respectively.

Modeling and simulation: A lumped parameter model for the cross flow heat exchanger is derived from heat balance and it is simulated using MATLAB. A physical model is developed by dimensional analysis followed by least square curve fitting experimental data.
Table 1: Steam vs water

\begin{tabular}{|c|c|c|c|c|}
\hline \multirow{2}{*}{$\begin{array}{l}\text { Volumetric Flow Rate } \\
\text { of Cold fluid (lpm) }\end{array}$} & \multicolumn{4}{|c|}{ Fluid Temperatures $\left({ }^{\circ} \mathrm{C}\right)$} \\
\hline & $\mathrm{t}_{\mathrm{ci}}$ & $\mathrm{t}_{\mathrm{co}}$ & $\mathrm{t}_{\mathrm{hi}}$ & $t_{\text {ho }}$ \\
\hline 0.44 & 29 & 69.5 & 112 & 99.5 \\
\hline 0.75 & 29 & 61.5 & 112 & 99.5 \\
\hline 1.28 & 29 & 56.0 & 112 & 99.5 \\
\hline 2.43 & 29 & 45.0 & 112 & 99.5 \\
\hline 3.48 & 29 & 38.5 & 112 & 99.5 \\
\hline 4.56 & 29 & 37.0 & 112 & 99.5 \\
\hline 4.68 & 29 & 36.5 & 112 & 99.5 \\
\hline 6.20 & 29 & 35.5 & 112 & 99.5 \\
\hline 6.64 & 29 & 35.0 & 112 & 99.5 \\
\hline 7.20 & 29 & 33.5 & 112 & 99.5 \\
\hline
\end{tabular}

Table 2: Steam vs $10 \%$ acetic acid

\begin{tabular}{|c|c|c|c|c|}
\hline \multirow{2}{*}{$\begin{array}{l}\text { Volumetric Flow Rate } \\
\text { of Cold fluid (lpm) }\end{array}$} & \multicolumn{4}{|c|}{ Fluid Temperatures $\left({ }^{\circ} \mathrm{C}\right)$} \\
\hline & $t_{\mathrm{ci}}$ & $t_{c o}$ & $\mathrm{t}_{\mathrm{hi}}$ & $t_{\text {ho }}$ \\
\hline 0.7 & 29 & 59.0 & 112 & 99.5 \\
\hline 1.0 & 29 & 53.0 & 112 & 99.5 \\
\hline 1.3 & 29 & 49.0 & 112 & 99.5 \\
\hline 1.5 & 29 & 48.0 & 112 & 99.5 \\
\hline 2.0 & 29 & 44.5 & 112 & 99.5 \\
\hline 2.2 & 29 & 42.5 & 112 & 99.5 \\
\hline 2.5 & 29 & 41.0 & 112 & 99.5 \\
\hline 2.7 & 29 & 39.5 & 112 & 99.5 \\
\hline 3.0 & 29 & 38.5 & 112 & 99.5 \\
\hline 3.5 & 29 & 36.5 & 112 & 99.5 \\
\hline 4.0 & 29 & 35.5 & 112 & 99.5 \\
\hline 4.5 & 29 & 35.0 & 112 & 99.5 \\
\hline
\end{tabular}

Mathematical modeling:

$$
\begin{aligned}
& \mathrm{t}_{\mathrm{o}}=\frac{\left(\mathrm{T}_{\mathrm{i}}+\mathrm{T}_{0}\right)+\mathrm{t}_{\mathrm{i}}(\mathrm{a}-1)}{\mathrm{a}+1} \\
& \mathrm{~T}_{\mathrm{o}}=\frac{\left(\mathrm{T}_{\mathrm{i}}(\mathrm{ab}+\mathrm{b}-\mathrm{a})\right)+\left(\mathrm{t}_{\mathrm{i}}(2 \mathrm{a})\right)}{\mathrm{a}+\mathrm{b}+\mathrm{ab}}
\end{aligned}
$$

Equation 1 and 2 represent the required mathematical model for the tube outlet temperature of the cold fluid $t_{o}$ and the outlet temperature of the hot fluid $\mathrm{T}_{0}$ respectively.

Physical Modeling: The physical model equation was developed using dimensional analysis follwed by least square curve fitting experimental data as follows:

$$
\mathrm{St}=0.332(\mathrm{Re})-0.5(\operatorname{Pr}) 0.667(\mathrm{x}) 0.997
$$

Simulation: The models derived above are simulated using MATLAB. Equation 1 and 2 are used to predict the outlet temperature of the cold and hot fluid, respectively. Simulation is done for all flow rates and $10 \%$ Acetic acid for which experiments were done and are plotted in Fig. 2 to along with the experimental values. 
Am. J. Applied Sci., 5 (10): 1318-1321, 2008

Table 3: Steam-water system

\begin{tabular}{|c|c|c|c|c|c|c|c|c|c|c|c|c|c|c|c|}
\hline \multicolumn{3}{|c|}{ Cold fluid (Water) } & \multicolumn{3}{|c|}{ Hot fluid (Steam) } & \multicolumn{3}{|c|}{ Heat transfer coefficient $\left(\mathrm{W} / \mathrm{m}^{2} \mathrm{~K}\right.$} & \multirow[b]{2}{*}{$\mathrm{C}^{*}$} & \multirow[b]{2}{*}{ NTU } & \multicolumn{2}{|c|}{$\begin{array}{l}\text { Surface } \\
\text { Effectiveness } \\
(\%)\end{array}$} & \multicolumn{2}{|c|}{$\begin{array}{l}\text { Fin } \\
\text { Effectiveness } \\
(\%)\end{array}$} & \multirow{2}{*}{$\begin{array}{l}\text { Exchanger } \\
\text { Effectiveness } \\
(\%) \\
\varepsilon\end{array}$} \\
\hline $\begin{array}{l}\mathrm{t}_{\mathrm{ci}} \\
\left({ }^{\circ} \mathrm{C}\right)\end{array}$ & $\begin{array}{l}\mathrm{t}_{\mathrm{co}} \\
\left({ }^{\circ} \mathrm{C}\right)\end{array}$ & $\begin{array}{l}\mathrm{M}_{\mathrm{c}} \\
(\mathrm{kg} / \mathrm{hr})\end{array}$ & $\begin{array}{l}\mathrm{t}_{\mathrm{hi}} \\
\left({ }^{\circ} \mathrm{C}\right)\end{array}$ & $\begin{array}{l}\mathrm{t}_{\mathrm{ho}} \\
\left({ }^{\circ} \mathrm{C}\right)\end{array}$ & $\begin{array}{l}\mathrm{M}_{\mathrm{h}} \\
(\mathrm{kg} / \mathrm{hr})\end{array}$ & $\begin{array}{l}\text { Hot fluid } \\
\text { ho }\end{array}$ & $\begin{array}{l}\text { Cold fluid } \\
\text { hi }\end{array}$ & $\begin{array}{l}\text { Overall } \\
\text { U }\end{array}$ & & & $\begin{array}{l}\text { Hot fl } \\
\text { ๆol }\end{array}$ & $\begin{array}{l}\text { Cold fluid } \\
\text { ๆ०2 }\end{array}$ & $\begin{array}{l}\text { Hot fluid } \\
\text { ๆf } 1\end{array}$ & $\begin{array}{l}\text { Cold fluid } \\
\text { үf2 }\end{array}$ & \\
\hline 29 & 69.5 & 26.063 & 112 & 99.5 & 189.56 & 294.295 & 318.274 & 148.677 & 0.301 & 3.25 & 97.36 & 97.10 & 96.24 & 95.95 & 89.80 \\
\hline 29 & 61.5 & 44.536 & 112 & 99.5 & 261.35 & 299.110 & 455.444 & 174.612 & 0.373 & 2.24 & 97.25 & 95.92 & 96.18 & 94.32 & 80.10 \\
\hline 29 & 56.0 & 76.132 & 112 & 99.5 & 360.26 & & 567.749 & 187.161 & 0.462 & 1.40 & 97.29 & 95.00 & 96.23 & 93.04 & 65.15 \\
\hline 29 & 45.0 & 144.88 & 112 & 99.5 & 375.74 & 276.527 & 768.300 & 195.925 & 0.843 & 0.71 & 97.45 & 93.43 & 96.46 & 90.86 & 42.76 \\
\hline 29 & 38.5 & 207.75 & 112 & 99.5 & 258.69 & 300.932 & 941.775 & 218.866 & 0.613 & 0.98 & 97.24 & 92.13 & 96.16 & 89.05 & 52.15 \\
\hline 29 & 37.0 & 272.29 & 112 & 99.5 & 270.99 & 272.6 & 1191.91 & 213.1 & 0.484 & 0.92 & 97.48 & 90.3 & 96.50 & 86.60 & 52.32 \\
\hline 29 & 36.5 & 279.48 & 112 & 99.5 & 260.76 & 310.359 & 1188.11 & 235.460 & 0.454 & 1.06 & 97.15 & 90.4 & 96.04 & 86.64 & 56.98 \\
\hline 29 & 35.5 & 370.38 & 112 & 99.5 & 232.30 & 350.476 & 1184.77 & 257.732 & 0.305 & 1.30 & 96.81 & 90.42 & 95.56 & 86.67 & 66.17 \\
\hline 29 & 35.0 & 396.63 & 112 & 99.5 & 250.50 & 336.081 & 1184.97 & 249.813 & 0.306 & 1.73 & 96.93 & 90.42 & 95.73 & 86.67 & 62.88 \\
\hline 29 & 33.5 & 430.19 & 112 & 99.5 & 185.46 & 298.426 & 1225.05 & 229.832 & 0.210 & 1.45 & 97.25 & 90.15 & 96.18 & 86.29 & 71.86 \\
\hline
\end{tabular}

Table 4: 10\% acetic acid-water solution

\begin{tabular}{|c|c|c|c|c|c|c|c|c|c|c|c|c|c|c|c|}
\hline \multicolumn{3}{|c|}{ Cold fluid (Water) } & \multicolumn{3}{|c|}{ Hot fluid (Steam) } & \multicolumn{3}{|c|}{ Heat transfer coefficient $\left(\mathrm{W} / \mathrm{m}^{2} \mathrm{~K}\right.$} & \multirow[b]{2}{*}{$\mathrm{C}^{*}$} & \multirow[b]{2}{*}{ NTU } & \multicolumn{2}{|c|}{$\begin{array}{l}\text { Surface } \\
\text { Effectiveness } \\
(\%)\end{array}$} & \multicolumn{2}{|c|}{$\begin{array}{l}\text { Fin } \\
\text { Effectiveness } \\
(\%)\end{array}$} & \multirow{2}{*}{$\begin{array}{l}\text { Exchanger } \\
\text { Effectiveness } \\
(\%) \\
\varepsilon\end{array}$} \\
\hline $\begin{array}{l}t_{\mathrm{ci}} \\
\left({ }^{\circ} \mathrm{C}\right) \\
\end{array}$ & $\begin{array}{l}\mathrm{t}_{\mathrm{co}} \\
\left({ }^{\circ} \mathrm{C}\right)\end{array}$ & $\begin{array}{l}\mathrm{M}_{\mathrm{c}} \\
(\mathrm{kg} / \mathrm{hr})\end{array}$ & $\begin{array}{l}\mathrm{t}_{\mathrm{hi}} \\
\left({ }^{\circ} \mathrm{C}\right) \\
\end{array}$ & $\begin{array}{l}\mathrm{t}_{\text {ho }} \\
\left({ }^{\circ} \mathrm{C}\right)\end{array}$ & $\begin{array}{l}\mathrm{M}_{\mathrm{h}} \\
(\mathrm{kg} / \mathrm{hr})\end{array}$ & $\begin{array}{l}\text { Hot fluid } \\
\text { ho }\end{array}$ & $\begin{array}{l}\text { Cold fluid } \\
\text { hi }\end{array}$ & $\begin{array}{l}\text { Overall } \\
\mathrm{U}\end{array}$ & & & $\begin{array}{l}\text { Hot } \mathrm{f} \\
\text { ๆo1 }\end{array}$ & $\begin{array}{l}\text { Cold fluid } \\
\text { ๆo } 2\end{array}$ & $\begin{array}{l}\text { Hot fluid } \\
\eta \mathrm{f} 1\end{array}$ & $\begin{array}{l}\text { Cold fluid } \\
\eta \mathrm{f} 2\end{array}$ & \\
\hline 29 & 59.0 & 41.833 & 112 & 99.5 & 208.07 & 323.241 & 465.378 & 184.196 & 0.417 & 2.65 & 97.05 & 95.85 & 95.89 & 94.22 & 82.73 \\
\hline 29 & 53.0 & 59.899 & 112 & 99.5 & 238.39 & 354.732 & 507.656 & 201.126 & 0.521 & 2.03 & 96.88 & 95.51 & 95.67 & 93.73 & 73.63 \\
\hline 29 & 49.0 & 77.993 & 112 & 99.5 & 258.67 & 329.924 & 560.069 & 199.920 & 0.625 & 1.54 & 97.03 & 95.06 & 95.87 & 93.13 & 64.26 \\
\hline 29 & 48.0 & 90.027 & 112 & 99.5 & 283.65 & 310.793 & 592.382 & 196.851 & 0.658 & 1.32 & 97.21 & 94.88 & 96.11 & 92.88 & 59.38 \\
\hline 29 & 44.5 & 120.20 & 112 & 99.5 & 308.94 & 302.882 & 670.823 & 201.207 & 0.806 & 1.01 & 97.38 & 94.17 & 96.35 & 91.89 & 49.89 \\
\hline 29 & 42.5 & 132.32 & 112 & 99.5 & 296.19 & 300.378 & 701.927 & 202.839 & 0.926 & 0.92 & 97.35 & 93.95 & 96.32 & 91.58 & 46.04 \\
\hline 29 & 41.0 & 150.58 & 112 & 99.5 & 299.57 & 298.823 & 758.716 & 206.611 & 0.958 & 0.86 & 97.32 & 93.55 & 96.27 & 91.03 & 43.95 \\
\hline 29 & 39.5 & 162.59 & 112 & 99.5 & 283.01 & 300.737 & 762.923 & 207.468 & 0.840 & 0.91 & 97.28 & 93.48 & 96.21 & 90.92 & 47.06 \\
\hline 29 & 38.5 & 180.73 & 112 & 99.5 & 284.60 & 307.148 & 765.471 & 210.970 & 0.760 & 0.93 & 97.27 & 93.44 & 96.09 & 90.88 & 48.42 \\
\hline 29 & 36.5 & 211.01 & 112 & 99.5 & 262.29 & 321.711 & 861.614 & 224.719 & 0.600 & 1.07 & 97.07 & 92.89 & 95.92 & 90.12 & 54.75 \\
\hline 29 & 35.5 & 241.26 & 112 & 99.5 & 259.86 & 331.528 & 929.630 & 234.192 & 0.50 & 1.12 & 96.98 & 92.35 & 95.81 & 89.29 & 57.60 \\
\hline
\end{tabular}

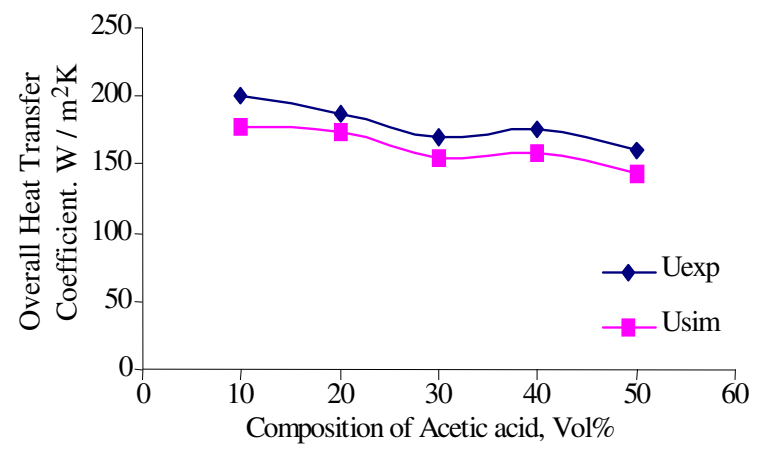

Fig. 2: Overall Heat Transfer Coefficient Vs Vol. flow rate of Cold fluid and composition of cold fluid

\section{RESULTS AND DISCUSSIONS}

The effects of different input variables on output variable are discussed in detail in the following sections.

Overall heat transfer coefficient for CFHE: As the volumetric flow rate of the tube side fluid is increased from $60 \mathrm{lph}$ to $300 \mathrm{lph}$, the overall heat transfer coefficient increased from 184.196 to $234.192 \mathrm{~W} /\left(\mathrm{m}^{2}\right.$ $\mathrm{K})$. For the same volumetric flow rates, the simulated values varied from 176.329 to $193.429 \mathrm{~W} / \mathrm{m}^{2} \mathrm{~K}$ respectively, i.e., almost same as experimental values.

Shell outlet temperature for CFHE: For the flow rate increments from $30 \mathrm{lph}$ to $300 \mathrm{lph}$, the outlet temperature of the shell side fluid remains constant as $99.5^{\circ} \mathrm{C}$, whereas the simulated values were 95 to $89^{\circ} \mathrm{C}$ respectively.

Tube outlet temperature for CFHE: For the flow rate increments from $30 \mathrm{lph}$ to $300 \mathrm{lph}$, the outlet temperature of tube side fluid varied from 59 to $35.5^{\circ} \mathrm{C}$, whereas the simulated values were 49 to $35^{\circ} \mathrm{C}$ respectively.

The results for the other compositions were similar to that obtained from the one considered here as the reference. From the above comparisons it can be said that the mathematical model developed for the system is very close. The deviation in shell outlet temperature may be because of the assumption of negligible condensation.

\section{CONCLUSION}

Experiments were conducted on a plate-fin type cross flow heat exchanger with different cold side flow 
rates and different compositions of cold fluid. The effect of these parameters on the shell outlet temperature, tube outlet temperature and overall heat transfer coefficients were studied. It was found that cold fluid outlet temperature decreases and the overall heat transfer coefficient increases with increases with increase in flow rate of cold fluid. Also the outlet temperature of cold fluid decreases and overall heat transfer coefficient increases with increase in composition of more heat capacity fluid. The overall effectiveness of heat exchanger was found to decrease with increase in temperature and increasing with increase in composition of high heat capacity fluid. A mathematical model of this system is developed, simulated using MATLAB and compared with the experimental values and it was found that the model predictions were close to experimental values. Finally a correlation for the calculation of film heat transfer coefficient is developed which can be used for both the cold and hot side.

\section{REFERENCES}

1. Kays, W.M. and A.L. London, 1904. Compact Heat Exchangers. $2^{\text {nd }}$ Edn., Mc Graw Hill Book Company, New York.

2. Ludwig, E.E., 1986. Applied process design for Chemical and Petrochemical plants, Vol. 3, $2^{\text {nd }}$ Edn.

3. Nuntaphan, A., T. Kiatsiriroat and C.C. Wang, 2005. Air side performance at low Reynolds number of cross flow heat exchanger using crimped spiral fins, International Communications in Heat and Mass Transfer 32: 151-165.

4. Hesselgreaves, J.E., 2002. An approach to fouling allowances in the design of compact heat exchangers, Applied Thermal Engineering $22,2002$.
5. Holman, J.P., 1997. Heat Transfer, $8^{\text {th }}$ Edn., Mc Graw-Hill Book Company, New York.

6. Ercan Ataer, O., 2004. An approximate method for transient behavior of finned tubes cross flow heat exchangers, Int. J. Refrigerat. 27: 529-539.

7. Zealsing, P., 2004. Heat exchanger design for good process performance, Chemical product finder, 120-122.

8. Perry, R.H. and D.W. Green, 1997. Perry's Chemical Engineering Hand Book, $7^{\text {th }}$ Edn., Mc Graw-Hill Company, New York.

9. Rohsenow, W.M., J.P. Hartnett and E.N. Ganic, 1985. Hand Book of Heat transfer Applications, $2^{\text {nd }}$ Edn., Mc Graw-Hill Company, New York.

10. Kern, D.Q., 2000. Process Heat Transfer, Tata Mc Graw Hill Edition.

11. Warren L Mc Cabe, Julian C. Smith and Peter Harriott, 1992. Unit Operations of Chemical Engineering, $5^{\text {th }}$ Edn., Mc Graw Hill International Edition.

12. Babu, B.V., 2004. Process Plant Simulation, Oxford University Press.

13. Kothandaraman, C.P. and S. Subramanyan, 2000. Heat and Mass Transfer Data Book, Tata Mc Graw Hill Edition.

14. Luyben, W.L., 1990. Process Modeling, Simulation And Control for Chemical Engineers, $2^{\text {nd }}$ Edn., Mc Graw Hill International Edition.

15. Rudra Pratap: Getting Started with MATLAB(Version 6.0,7.0), Oxford University Press. 